\title{
天竜川支川三峰川流域に扣ける崩壊土砂量の数的解析について
}

\author{
田浦 秀春* ・川崎＼cjkstart達*

\section{Numerical Analysis of Landslide Degradation Volume in the River Mibu Basin} \\ by Hideharu Taura and Tōru Kawasaki
}

\begin{abstract}
In the River Mibu Basin, it was numerical analyzed to the relation between landslide degradation volume and the factors of rainfall, slope, river density and vegetation.

For this study, 500M Grid was covered on the River Mibu Basin, and these factors were surveyed in every grid field.

We expressed the relation by function, and obtained the function of coefficient.

Using this function, we can be forecast some landslide degration volume according to rainfall in the area.
\end{abstract}

\section{I 、 まえがき}

河川の流域に打ける崩壊土砂量は, 河床変動量, ダ ムの貯水池の堆砂等の基礎となるものであるから，河 川の利水, 治水雨面に执いて, 極めて重要なものであ る。

このために色々と研究が行なわれてきたが，大部分 は定性的なものであって, 定量的に解析した例は極め て少ない。この報告は, 天竜川支川三峰川流域を対象 として, 流域に打ける崩壊土砂量と, これに影響を拉 よぼす降雨量, 地形, 地質等各種要因々の関係を, 数 的に解析したものである。

このために，建設省関係で行なわれてきた崩壊調査 の諸データをもとにして, これに降雨量, 地形等の諸 要因を加光, メッシュマップと統計的手法を用いて解 析を行なった。

この方法によると, 崩壊土砂量と各種要因との関係 が数的に解析でさるのみならず，その結果を利用し て, 各種の降雨量の場合に抢敄る崩壊土砂量の予測に まで，発展させることができる。

なおこの報告書の実験にあたり，建設省天竜川上流 工事事務所調査課長原勝敏殿, 係長橋爪稠殿より, 貴 重な資料を貸与していただき，また種々便宜をはから っていただいた。冒頭に附記して特に感謝の意を表す る次第である。

*パシフィック航業栋式会社

「写真測量」Vol. 12 No. 11973

\section{II . 基礎的な考え}

崩壊を起す要因としては, 降雨, 地震等のように直 接的な誘因となるものと, 地質, 斜面の勾配等のよう に潜在的な素因と考学られるものとの二つがある。し かしこの二種類の要因は性格が全然異なるから，同一 に論ずることは出来ない。したがってここでは次のよ らに二段階に分将て考えた。

\section{(1) 雨量解析}

全流域を $500 \mathrm{~m}$ 間隔のメッシュで打抒い，既設の雨 量データをもとにして, 各メッシュの降雨量を推定し た。このためには, 降雨を地形性降雨と非地形性降雨 に分けて, 各々を数式化し, 各雨量観測所の雨量デー 夕を用いて式の係数を求め,さらにその結果を用いて メッシュ毎の雨量を計算した。な掞この方法による地 点雨量推定の䛊差は，約15\%〜20\%である。

つぎに雨量を数個の階級に分けて，全流域のメッシ ュをその階級別に区分した。そして各階級毎に，次の ような素因についての解析を行なった。

\section{(2) 素因の解析}

素因には, 斜面の勾配, 地質, 風化の度合い, 山腹 の形態, 地下水の状況, 集水状況, 植生等があげられ るが，この中で斜面の勾配は，他の素因に比べて若干 性質が異なるように思われる。それは他の素因がどの よらであっても, 地面が傾斜していなければ, 絶対に 崩壊は起きない筈だからである。 
そこでここでは勾配を基本的な素因と考えて，他の 素因はそれに二次的に影響するものであると考えた。 そらするとこれらの関係は, 次の式であらわすことが できる。

$$
A=\alpha_{1} \beta_{1} \cdot \alpha_{2} \beta_{2} \cdots \cdots \cdots \cdot \alpha_{m}{ }^{\beta n} \cdot V
$$

ただし， $A$ : 崩壤面積

$V$ : 斜面の勾配に基く崩壊面積

$\alpha_{1}{ }^{\beta_{1}}, \cdots, \alpha_{n}{ }^{\beta n}:$ それぞそ $n$ 個の素团に基く修 正係数

な特これからは，測定し易い崩壊面積について述べ るが，崩壊土量についても，同じ方法で解析すること ができる。

\section{III . 基本図ならびにメッシュマップの作製}

河川の流域の崩壊土量の推定に必要と思われる 4 種 の素因の, 斜面の勾配, 地質, 植生, 谷密度之, 崩壊 面積について, 地図, 航空写真ならびに現地調查等に よって，全流域の基本図を作製した。つぎに素因につ いては，さらにそれを記号化したメッシュマップを作 製した。

この素因の中で谷密度は, 直接崩壊に影響を与える ものではないが，次のような考えからとり入れること にした。一般に山地に扟子る水系模様は, 斜面が生成 された当初はその最大勾配の方向をとり, しかも単調 な筈である。しかし風化が進むにしたがって斜面は侵 蝕をらけるので，水系模様は細かく複雑になる。した がって山腹の風化の程度をしめす一つの指標として, 水系模様の中で数值化し易い谷密度をとりいれた。

\section{IV. 解 析}

（1）降雨量の解析 (詳細については, 参考文献(1)参照)

任意の地点に和ける降雨量を次の式であらわし, 式 の係数を既設の観測所の雨量データを用いて決定し た。式の中で $R_{1}$ は非地形性降雨を， $R_{2}$ は地形性降雨 をあらわすものである。

$$
\begin{aligned}
R= & R_{1}+R_{2} \\
R_{1}= & A_{1}+A_{2} X+A_{3} Y \\
R_{2}= & B_{1}(H-\bar{H})+B_{2}(\bar{H}-\overline{\bar{H}}) \\
& +B_{3}(\overline{\bar{H}}-\overline{\bar{H}})+B_{4}(\overline{\bar{H}})
\end{aligned}
$$

ただし， $R$ : 地点雨量

$(X, Y)$ : 地点の平面座標 $(H-\bar{H}), \cdots,(\overline{\bar{H}}-\overline{\bar{H}})$ : 各々 $4 \mathrm{D}, 8 \mathrm{D}, 16 \mathrm{D}$ の地形の波の振幅, Dは卓越した地形の 波長の $1 / 4$

$(\overline{\overline{\bar{H}}}) ： 4 \mathrm{D}, 8 \mathrm{D}, 16 \mathrm{D}$ の地形の消去された残り の長波長の地形

$A_{1}, \cdots, B_{4}$ : 係数
ただし状況により非地形性降雨の部分は，二次式を 用いることがある。

次に式(2)を用いて, 各々のメッシュの雨量を計算 し，その結果に基いて全域のメッシュを数筒の雨量の 階級にわけた。

\section{（2）素因の解析}

各雨量の階級毎に必要数のメッシュを抽出して, 次 の計算を行なった。

1. 斜面の勾配

斜面の勾配を $n^{\prime}$ 個のカテゴリーに分け，各カテゴリ 一にあたえる数值 $V$ を，次の式で決定した。

$$
V_{k}=S_{k} / a_{k} \times 0.25
$$

ただし， $k=1, \cdots, n^{\prime}$. カテゴリ一区分

$S_{k}$ ：カテゴリーkに属する部分の崩壊面積の 総和

$a_{k}$ : カテゴリー $k$ に属する部分の総面積 $\left(K^{2}\right)$

0.25: $500 \mathrm{~m}$ メッュに換算するための係数

次に式( 3 )を用いて，各メッシュのVの值を計算し た。

2. 他の素因

各素因毎に若干個のカテゴリーにわけ，各カテゴリ 一にあたえる係数 $\alpha$ を次の式で決定した。

$$
A_{l}=\alpha_{l} V_{l}
$$

ただし， $l=1,2, \cdots, n^{\prime \prime}$. カテゴリ一区分

$A_{l}, V_{l}$ : カテゴリー $l$ 属するメッシュの崩壊 面積ならびに $V$ の值の総和

つぎに次式を用いて，各係数のウエイト $\beta$ を決定し た。

$$
A_{i}=\alpha_{1 i}{ }^{\beta_{1}} \cdot \alpha_{2 i}^{\beta_{2}} \cdot \alpha_{3 i}^{\beta_{3}} \cdot V_{i}
$$

ただし， $A_{i}, V_{i}:$ メッシュ $i$ にお打る崩壊面積ならびに $V$ の值

$\alpha_{1 i}, \alpha_{2 i}, \alpha_{3 i}$ : メッシュにおいて素因 1，2，3に 基く係数

\section{$\nabla$. 雨量の階級毎の崩壊面積の計算}

式(5)を用いて, 雨量の階級毎に各メッシュの崩壊 面積を計算して，メッシュマップを作製し，次にこれ を用いて全流域の崩壊面積を算出した。

\section{VI. 将来の予測}

式(2)，(5) を用いると, 将来に和ける崩壊士砂量 の概略を，予想することができる。

しかし崩壊には免疫性が考它られるので，このよう な解析を数回行なって式 (5)の係数の変化を解析すれ ば，より合理的な予測值を求めることができょう。 


\section{VII. 三峰川流域における実験}

\section{（1）過去に行なわれた実態調査}

天竜川流域では，昭和36年 6 月27日の豪雨の際に， 大崩壊を生じた。このため建設省天竜川上流工事事務 所では，昭和 42 年国際航業株式会社に委托して，竜東 地区の実態調查を実施された。その中で三峰川流域に ついては，田浦が担当して崩壊個々の地点について， 数的解析を行なった。したがって今回の降雨量につい ては，その際の解析の結果を利用させてもらった。

\section{(2) 降雨量の解析 ${ }^{(3)}$}

三峰川流域に配置されている雨量観測所は，戸台， 伊那里，小瀬戸，鹿塩，荒川，前浦，無名の 7 箇所で あった。これに対し流域は，東西約 $10 \mathrm{k}$, 南北約 $20 \mathrm{k}$ の範囲にわたっているから，これを次の 3 地区にわけ て計算した。

第 1 地区 無名, 伊那里, 前浦, 小瀬戸, 鹿塩の観 測所に囲まれた地区

第 2 地区 戸台，伊那里，前浦，小瀬戸，荒川の観 測所に囲まれた地区

第 3 地区 鹿塩, 小瀬戸，荒川と第 2 地区で決定し

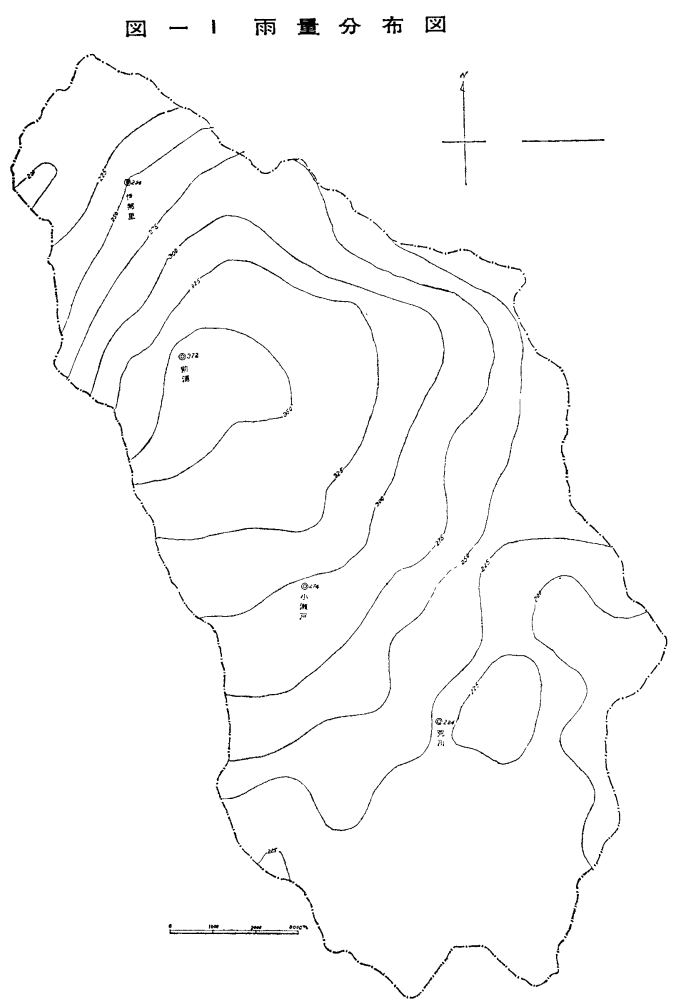

図 1 雨量分布図
た中から点を撰点して，鹿塩一小瀬戸一 荒川の線以南の地区

このため昭和36年 6 月 27 日の各観測所の日雨量と地 形データをもとにして，式(2)の係数を決定した。つ ぎに全地域を $500 \mathrm{~m}$ 間隔のメッシュで抒捻い，各メッ シュの交点の降雨量を計算すると共に，全流域の雨量 分布図（図1）を作った。

なおこの持による降雨量の推定精度をチェックす るために，戸台，伊那里，小瀬戸，鹿塩，荒川のデー タをもとにして, 同じ方法で前浦の雨量を推定して, 実 測值と比較した。その結果は表 1, 2 のと利りである。

表 1 日雨量一覧表（前浦）(単位は $\mathrm{mm}$ )

\begin{tabular}{|c|c|c|c|c|c|c|c|}
\hline 月日 & 推定值 & 実測值 & 誤 差 & 月日 & 推定值 & 実測值 & 愦 差 \\
\hline 5. 3 & 32.7 & 38.3 & -5.6 & 6.24 & 30.3 & 30.5 & -0.2 \\
\hline 4 & 63.2 & 54.6 & 8.6 & 25 & 20.7 & 19.8 & 0.9 \\
\hline 7 & 2.4 & 2.1 & 0.3 & 26 & 44.2 & 40.0 & 4.2 \\
\hline 11 & 32.6 & 36.3 & -3.7 & 27 & 352.1 & 371.9 & -19.8 \\
\hline 12 & 40.2 & 44.8 & -4.6 & 28 & 55.3 & 57.6 & -2.3 \\
\hline 18 & 25.0 & 26.4 & -1.4 & 1 & 4.2 & 5.7 & -1.5 \\
\hline 21 & 1.8 & 0.0 & 1.8 & 2 & 1.4 & 1.5 & -0.1 \\
\hline 23 & 10.9 & 8.8 & 2.1 & 3 & 2.8 & 1.1 & 1.7 \\
\hline 24 & 2.8 & 5.4 & -2.6 & 4 & 35.0 & 33.0 & 2.0 \\
\hline 28 & 33.1 & 30.2 & 2.9 & 5 & 2.9 & 3.5 & -6.0 \\
\hline 29 & 8.7 & 13.5 & -4.8 & 6 & 7.0 & 1.9 & -2.1 \\
\hline 6. 7 & 27.1 & 21.6 & 0.5 & 9 & 9.4 & 9.8 & -0.4 \\
\hline 8 & 4.7 & 5.0 & -0.3 & 10 & 1.3 & 0.9 & 0.4 \\
\hline 9 & 47.5 & 50.5 & -3.0 & 11 & 7.7 & 3.4 & 4.3 \\
\hline 10 & 1.1 & 1.9 & -0.8 & 12 & 7.2 & 7.2 & 0 \\
\hline 13 & 8.9 & 1.7 & -0.8 & 16 & 10.5 & 16.5 & -6.0 \\
\hline 14 & 18.9 & 20.9 & -2.0 & 24 & 8.0 & 14.5 & -6.5 \\
\hline 16 & 6.6 & 6.9 & -0.3 & 29 & 0 & 2.8 & -2.8 \\
\hline 21 & 0.2 & 1.1 & -0.9 & 1. 1 & 8.5 & 4.4 & 4.1 \\
\hline 23 & 2.7 & 4.0 & -1.3 & 2 & 3.5 & 3.4 & 1.1 \\
\hline
\end{tabular}

表 2 精度分析表（単位は $\mathrm{mm}$ )

\begin{tabular}{|c|c|c|c|}
\hline & $0 \sim 10$ & $10 \sim 50$ & $50 \sim$ \\
\hline$\sigma$ & 1.8 & 3.8 & 11.0 \\
$r$ & 4.1 & 26.2 & 129.5 \\
$\sigma / r$ & 0.44 & 0.14 & 0.09 \\
標 本 数 & 22 & 14 & 4 \\
\hline \multicolumn{3}{|c}{} \\
\hline
\end{tabular}

\section{（3）傾斜区分図の作製}

航空写真, 1/1,000 地図, 1/50,000 地図を用いて, 全域の傾斜区分図（図 2 次頁）を作製した。この際傾斜 区分は
1. $0^{\circ} \sim 25^{\circ}$
2. $25^{\circ} \sim 40^{\circ}$
3. $40^{\circ}$ 以上

の三通りとした。つぎに(2)のメッシュをかけ，各メッ シュ毎に傾斜区分毎の面積の割合を求めた。

\section{（4）崩壊分布図の作製}

貸与された報告書(2) の中の崩壊地点の分布図を用い た。これに(2)のメッシュをかけ，各メッシュ毎に傾斜 区分毎の崩壊面積を測定した。 


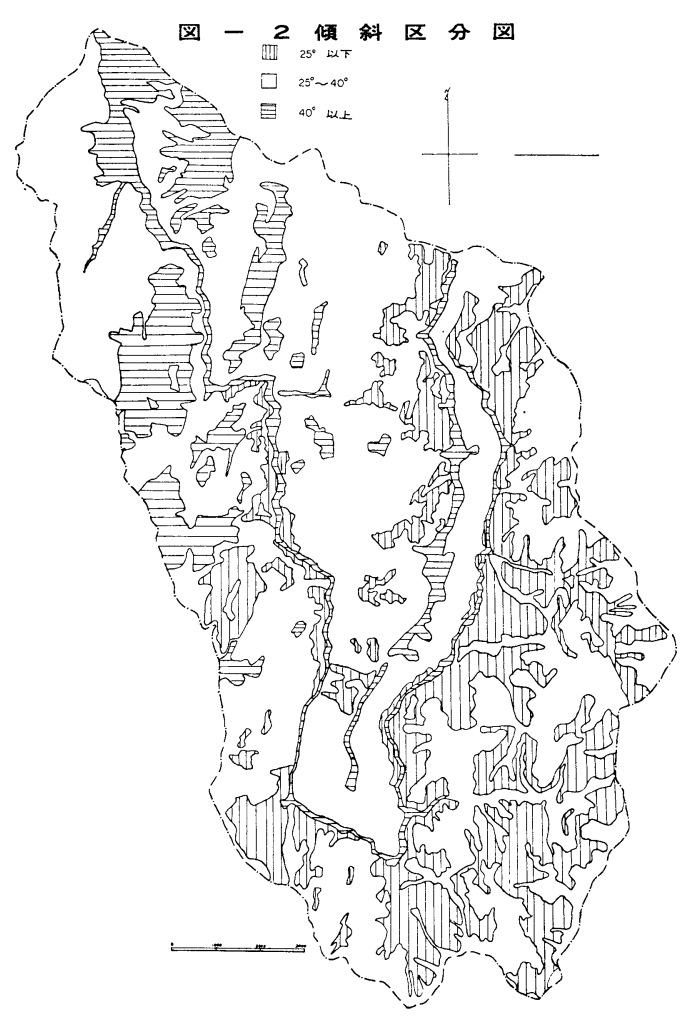

図 2 傾傾区分図

\section{（5）地質図の作製}

貸与された報告書 ${ }^{(3)}$ の中の地質図 (図 3 ) にしたがっ て, 次の 5 種類の岩質に区分した。
1. 領家花崗岩
2. 压砕岩
3. 三波川結昌片岩
4. 古生層
5. 中生層

つぎに全域に(2)のメッシュをかけ，メッシュマップ を作製した。

\section{（6）植生分布図の作製}

航空写真を用いて全域の植生分布図，ならびにその メッシュマップを作製した。

\section{（7）水系図の作製}

三峰川本流をもとにして第三次支川迄を測定した。 その大きさは $1 / 50,000$ 図上に示されている明瞭な谷を 流れる水系迄とし，上端は谷頭部とした。詳細は図 4 にしめすと呿りである。つぎにこれに(2)のメッシュを かけて，各メッシュ毎にその中の水系の総延長を測定 した。

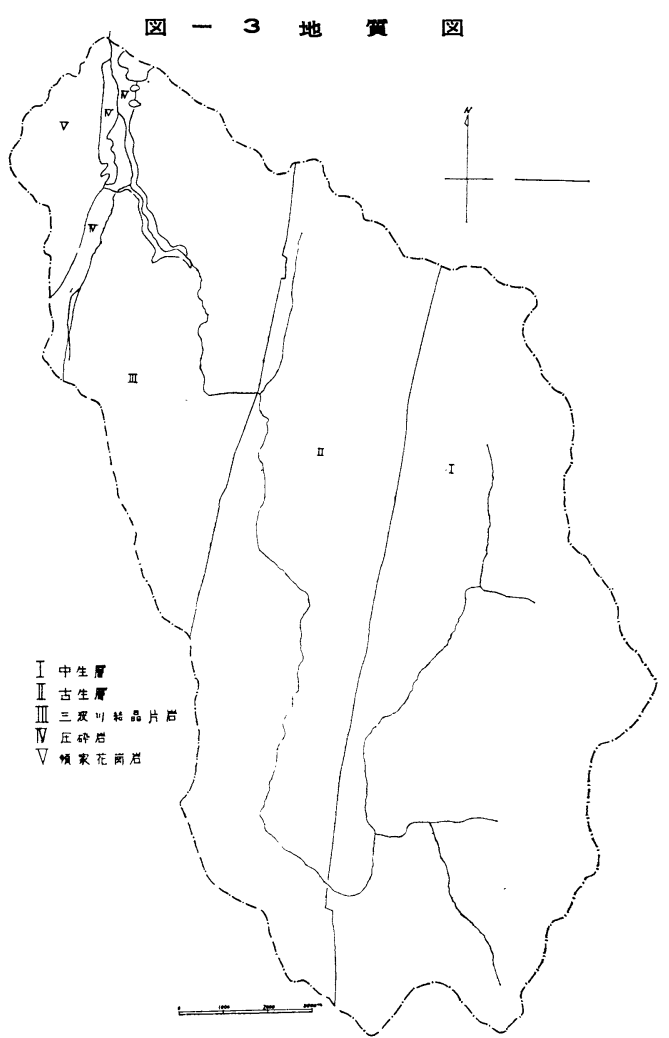

図 3 地 質 図

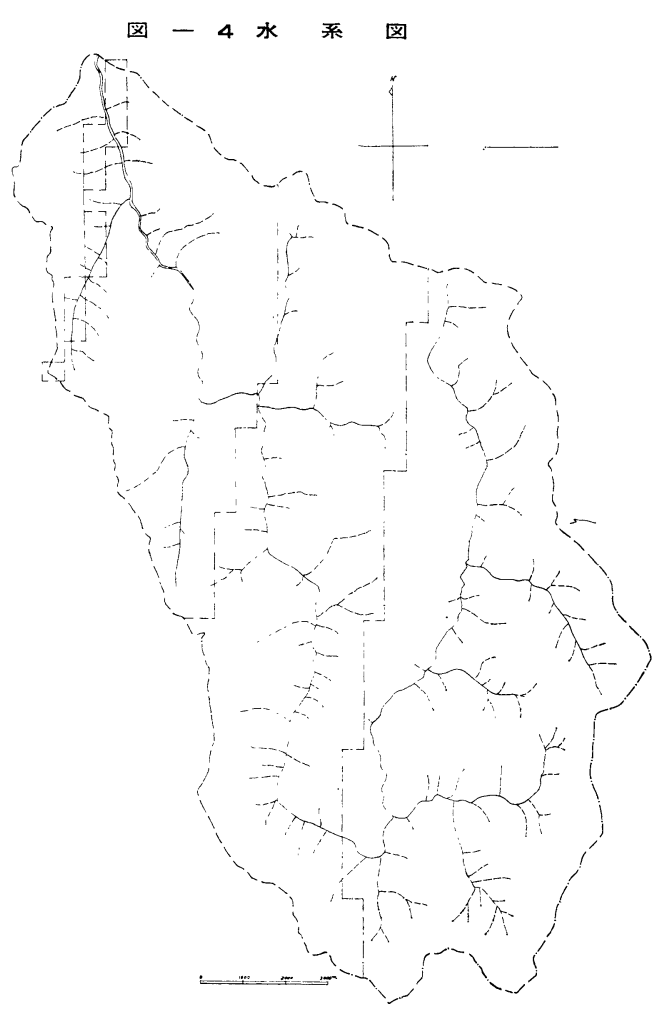

図 4 水系図 


\section{（8） 解 析}

1. 崩壞面積 $(V)$ の算定

降雨量にもとづいて各メッシュを次の 3 群に区分し た。

第 1 群 $325 \mathrm{~mm}$ 以上

第 2 群 $325 \mathrm{~mm} \sim 225 \mathrm{~mm}$

第 3 群 $225 \mathrm{~mm}$ 以下

つぎに各群毎に，傾斜と地質のカテゴリ一間の組合 わせをとり，単位メッシュ $(0.5 \mathrm{k} \times 0.5 \mathrm{k})$ 当りの崩壤 面積を求めた。その状況を表 3 亿しめす。

\section{表 3 崩壊面積 $(V)$ 一覧表}

\begin{tabular}{|c|c|c|c|c|c|}
\hline 雨 量 & 地 䫓 傾 斜 & $40^{\circ}$ 以上 & $40^{\circ} \sim 25^{\circ}$ & $25^{\circ}$ 以下 & 平 均 \\
\hline \multirow{2}{*}{$\begin{array}{l}325 \mathrm{~mm} \\
\text { 以 } \\
\text { 上 }\end{array}$} & 三波川結昌片岩 & $10,120^{*}$ & 5,032 & 2,270 & 3,824 \\
\hline & 古 生 層 & $3,80.9$ & 2,381 & $146^{*}$ & 2,508 \\
\hline \multirow{5}{*}{$\begin{array}{c}325 \mathrm{~mm} \\
? \\
225 \mathrm{~mm}\end{array}$} & 領家花嵲 岩 & \multirow{5}{*}{$\begin{array}{l}3,809 \\
4,560\end{array}$} & 4,133 & $3,197^{*}$ & 4,066 \\
\hline & 圧 砕 岩 & & 1,992 & 740 & 1,733 \\
\hline & 三波川結昌片岩 & & 3,800 & 1,078 & 2,817 \\
\hline & 古 生 層 & & 1,730 & $146^{*}$ & 2,041 \\
\hline & 中 生 & & 2,656 & 0 & 3,354 \\
\hline \multirow[b]{2}{*}{$225 \mathrm{~mm}$} & 領家花崗岩 & & 4,133 & $3,194^{*}$ & 4,066 \\
\hline & 压确岩 & & 1,992 & 749 & 1,733 \\
\hline 以 & 三波川結昌片岩 & & 3,800 & 1,078 & 2,817 \\
\hline & 古 生 層 & 2,889 & 1,104 & $146 *$ & 1,652 \\
\hline & 生 & 5,964 & 2,519 & 0 & 4,257 \\
\hline \multicolumn{2}{|l|}{ 平 } & 4,691 & 2,565 & 909 & 2,904 \\
\hline
\end{tabular}

ただし崩壊面積の単位は $400 \mathrm{~m}^{2}$

*はデータ僅少のため信頼性の低いもの。

表 3 亿よれば，各岩質内では雨量が多くなる程，ま た傾斜が大きくなる程崩壊面積が大きくなっている。 また岩質間では古生層の崩塤面積が一番少さい。これ らは一応妥当な結果であるら。ただし中生層 $\left(40^{\circ}\right.$ 以 上）の $325 \mathrm{~mm} \sim 225 \mathrm{~mm}$ と $225 \mathrm{~mm}$ 以下との間で逆転 しているが，これは水系密度の影響によるもののよう である。

そこでこの実験では，式(5)の考方方を若干かえて 表 3 の数值を基礎にして，これて谷密度による影響を 修正することを考えた。

\section{2. 要因の吟味}

各要因と崩壊面積との関係を吟味するために，単相 関係数を求めた。その状況を表 $4,5,6$ 亿しめす。た だし傾斜の闌は表 3 の値をそれぞれ各メッシュの傾斜 区分毎に代入して求めた值を用い，植生は各カテゴリ 一を崩壊面積との相関関係数が最大になるように数量 化 ${ }^{(3)}$ した值を用いた。

表 4, 5, 6 亿よると, 植生と崩壊面積の間の単相関係 数が小さいから，省略しても差支えない。これは今回 の降雨量が最低 $200 \mathrm{~mm} /$ 日位もあって大きいから，影
表 4 単相関係数（1 群)

\begin{tabular}{|c|c|c|c|}
\hline 水系 & & & -0.0713 \\
\hline & & -0.0023 & 0.0195 \\
\hline 崩壊面積 & 0.2998 & 0.5456 & -0.0429 \\
\hline & 傾 斜 & 系 & 植 \\
\hline
\end{tabular}

表 5 単相関係数 $(2$ 群 $)$

\begin{tabular}{|c|c|c|c|}
\hline $\begin{array}{l}\text { 水 系 } \\
\text { 傾 斜 } \\
\text { 崩壊面積 }\end{array}$ & 0.1981 & $\begin{array}{l}0.0987 \\
0.5682\end{array}$ & $\begin{array}{r}-0.0283 \\
0.0041 \\
0.0611\end{array}$ \\
\hline & 傾 & 水 & 植 \\
\hline
\end{tabular}

表 6 単相関係数 ( 3 群)

\begin{tabular}{|c|c|c|c|}
\hline $\begin{array}{ll}\text { 水 系 } \\
\text { 傾 斜 } \\
\text { 崩 壊面穔 }\end{array}$ & 0.2226 & $\begin{array}{l}0.1888 \\
0.5408\end{array}$ & $\begin{array}{l}0.0491 \\
0.0252 \\
0.0491\end{array}$ \\
\hline & 傾 斜 & 水 系 & 植 \\
\hline
\end{tabular}

響度が薄れてきたのではなかららか。降雨量がもっと 小さい場合には，植生が大きく作用してくるかも分ら ない。

\section{3. 水系（谷）密度の修正}

各群毎に次の式を用いて，水系 (谷) 密度の修正係 数を求めた。

$$
A=(a+b W) V
$$

ただし， $A$ : メッシュ内の崩壞面積実測值 $\left(\mathrm{m}^{2}\right)$

$$
V \text { : 表 } 3 \text { の值を代入乙て求めたメッシュ内の }
$$
崩壊面積 $\left(\mathrm{m}^{2}\right)$

$W:$ メッシュ内の水系(谷)密度 $(\mathrm{m})$

$a, b:$ 係数

その結果次の修正係数が得られた。

第 1 群 $0.1959+0.0111 \times W$

第 2 群 $0.1327+0.0114 \times W$

第 3 群 $0.2390+0.0067 \times W$

な特水系（谷）密度Wについては，予め次のような 重味をつけた。

図4 亿扮いて

$\begin{array}{ll}2 \text { 条実線の部分 } & 0 \\ 1 \text { 条実線の部分 } & 0.25 \\ \text { 破線の部分 } & 1\end{array}$

これは河谷の幅が大きい程，侵蝕が進んで拈ると考 えられるので，逆媇しい崩壊に対しては，それだけ 安定性が増しているともいえる。したがって河谷の幅 の大小にしたがって重味をつける事を考光，統計的に 上記の数值を導いた。

\section{4. 解析の精度}

以上の数值を用いてメッシュ毎の崩壊面積を逆算 
し，実測値との重相関係数を求めた。その結果次のよ らに一応満足する值が得られた。

\section{表 7 重相関係数}

\begin{tabular}{|c|c|c|c|}
\hline 第 1 群 & 第 2 群 & 第 & 群 \\
\hline 0.8435 & \multicolumn{2}{|c|}{0.7885} & 0.6904 \\
\hline
\end{tabular}

\section{5. 崩壊土量の解析}

これ迄は崩壊面積について解析を進めてきたが，報 告書 ${ }^{(2)}$ とよるサンプリング調査によって, 崩壊面積 と崩壊土量が求められていて，その関係は次の上らに あらわされる。したがってこれを用いることによって 相互に換算することができる。

\section{表 8 崩壊面積 $1 \mathbf{m}^{2}$ 当りの崩壊土量（単位は $\mathrm{m}^{3}$ )}

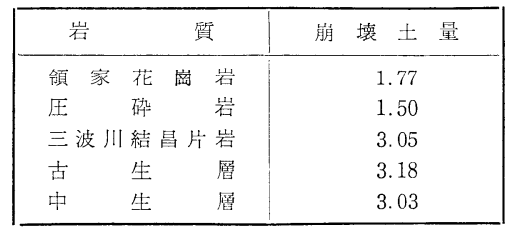

\section{9. 将来の予測}

以上の結果を用いると， 3 群に分れた各降雨量に応 ずるメッシュ毎の崩壊面積 (土量) を, 容易に推定す ることができる。一例として全域に $325 \mathrm{~mm}$ ～ $225 \mathrm{~mm}$ の日雨量があった場合の,メッシュ毎の崩壊面積を計 算すると図 7 のようになった。

\section{VIII. あとがき}

個々の崩壊については，多くの専門家によって色々 と研究されているが，未だもって充分に解明されてい ない。したがって現時点において，広い河川の流域に おケる，崩壊土砂量を，物理的に解析しようとするの は至難の事であらら。しかしその必要性から考光て, 『幾らかでもましな方法』が提案されるならば, 少し でも現在の急場をしのぐことができるのではなからう か。

この報告は以上の趣旨にもとづいて, 研究を進め実 験したものである。勿論完全といらには程遠い状況で はあるが，幾分でも公共の持役に立つならば，この上 ない幸でである。

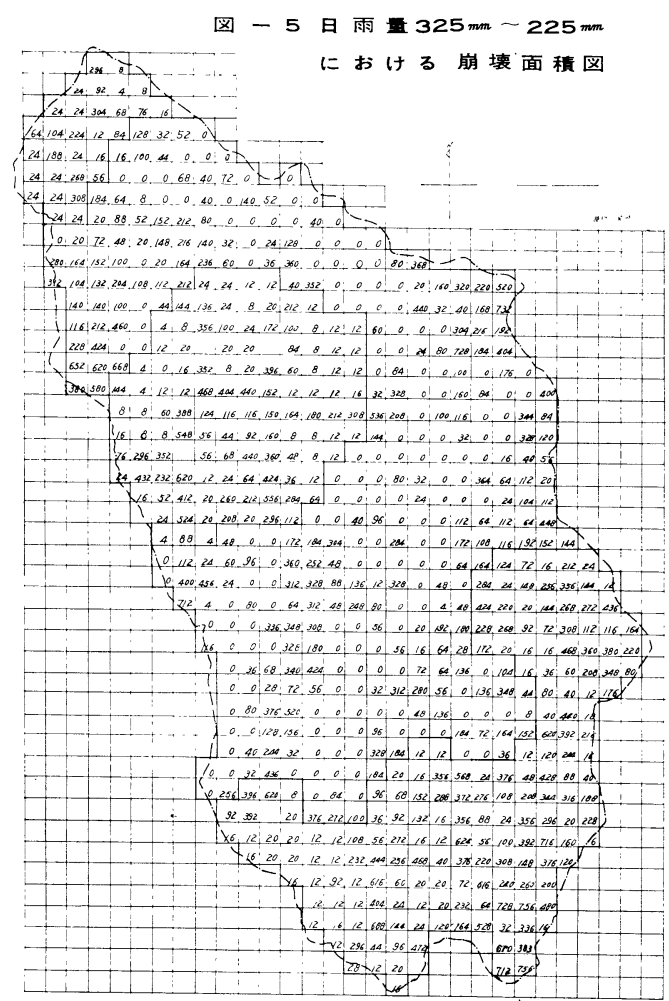

図 7 日雨量 $325 \mathrm{~m} \mathrm{~m} \sim 225 \mathrm{~mm}$ における崩壊面積図

\section{参考文献}

(1) 丸安隆和, 田浦秀春: “ある流域内の地点雨量分布の推 定方式の研究” 写真测量 Vol. 4, No. 2, 1965

（2）中部地方建設局天竜川工事事務所：“竜東流域地質調査 報告書” 1967

(3) 中部地方建設局天竜川工事事務所：“崩壊土量の解析” 1967 